Human palaeontology and prehistory

\title{
New data on Sicilian prehistoric and historic evolution in a mountain context, Vallone Inferno (Scillato, Italy)
}

\section{Nouvelles données sur l'évolution préhistorique et historique dans un contexte montagneux, le Vallone Inferno (Scillato, Italie)}

\author{
Vincenza Forgia a , Patricia Martín ${ }^{\text {b,*,c }}$, Juan Manuel López-García ${ }^{i}$, Andreu Ollé ${ }^{b, c}$, \\ Josep Maria Vergès ${ }^{b, c}$, Ethel Alluée, ${ }^{b, c}$, Diego E. Angelucci ${ }^{d}$, Massimo Arnone ${ }^{j}$, \\ Hugues-Alexandre Blain $^{\text {b,c }}$, Francesc Burjachs ${ }^{\mathrm{b}, \mathrm{c}, \mathrm{e}}$, Isabel Expósito ${ }^{\mathrm{b}, \mathrm{c}}$, Andrea Messina ${ }^{\mathrm{f}}$, \\ Llorenç Picornellg, Anna Rodríguez $^{\text {b,c }}$, Giuseppa Scopelliti ${ }^{a}$, Luca Sineof ${ }^{f}$, \\ Giovanni Virruso $^{\mathrm{h}}$, Enrico Alessi ${ }^{\mathrm{h}}$, Giovanni Di Simone ${ }^{\mathrm{a}}$, Juan Ignacio Morales ${ }^{\mathrm{b}, \mathrm{c}}$, \\ Enrico Pagano ${ }^{\mathrm{a}}$, Oscar Belvedere ${ }^{\mathrm{a}}$ \\ a Dipartimento di Beni Culturali, Università di Palermo, Viale delle Scienze-Ed.12, 90128 Palermo, Italy \\ b IPHES, Institut Català de Paleoecologia Humana i Evolució Social. C/Marcel.li Domingo, s/n. Campus Sescelades (Edifici W3), 43001 Tarragona, Spain \\ c Àrea de Prehistòria, Universitat Rovira i Virgili (URV), Fac. de Lletres, Avinguda Catalunya, 35, 43002 Tarragona, Spain \\ d Dipartimento di Lettere e Filosofia, Università degli Studi di Trento, via T. Gar 14 41, 38122 Trento, Italy \\ e ICREA, Barcelona, Spain \\ ${ }^{f}$ Dipartimento di Biologia Ambientale e Biodiversità, Università di Palermo, Via Archirafi, 18, 90123 Palermo, Italy \\ g Seminari d'Estudis i Recerques Prehistòriques. Department Prehistòria, H. Antiga i Arqueologia. Universitat de Barcelona. C/Montalegre $n^{0}$ 6, 08001 \\ Barcelona, Spain \\ h Museo Luigi Donini, via fratelli Canova, $n^{\circ} 49,40068$ San Lazzaro di Savena (BO), Italy \\ i Gruppo di Ricerca di Paleobiologia e Preistoria, Dipartamento di Studi Umanistiche, Università degli Studi di Ferrara, C.so Ercole 1 d'Este 32, I-44121, \\ Ferrara, Italy \\ j Geologo - Progetto CARG - Dipartimento di Scienze della Terra e del Mare, Università di Palermo, Via Archirafi n. 22 - 90123 Palermo, Italy
}

\section{A R T I C L E I N F O}

\section{Article history:}

Received 28 August 2012

Accepted after revision 12 November 2012

Available online 30 January 2013

Presented by Yves Coppens

\section{Keywords:}

Multidisciplinary study

Neolithic-medieval period

Pastoral activities

Environmental changes

Madonie mountain range

Sicilnie

Sicile

\begin{abstract}
A B S T R A C T
Vallone Inferno rock-shelter is an archaeological site located in the Madonie mountain range in Sicily. Archaeological excavation and research have provided a long prehistoric and historic sequence from the Neolithic to the medieval period, this being the most complete work in this area at present. In this paper we present the preliminary data provided by a multidisciplinary study based on pottery, lithic, human, faunal and plant remains. Stratigraphic studies have identified four complexes, of which complex 3 has provided almost all the archaeological remains. ${ }^{14} \mathrm{C}$ AMS dates, obtained from four samples, place the human activities between $2601 \mathrm{cal} \mathrm{BC}$ and $644 \mathrm{cal}$ AD. These dates are coherent with the cultural attribution of the ceramic and lithic remains. Macrofaunal and plant remains show a persistent use of the shelter for pastoral activities. Environmental data, obtained from microvertebrate and archaeobotanical remains, show the aridification and opening of the landscape from the base to the top of the sequence as a consequence of the human impact.
\end{abstract}

(C) 2012 Académie des sciences. Published by Elsevier Masson SAS. All rights reserved.

\footnotetext{
* Corresponding author.

E-mail address: patrimr9@gmail.com (P. Martín).
} 


\section{R É S U M É}

Mots clés :

Étude multidisciplinaire

Période néolithique-médiévale

Activités pastorales

Changements environnementaux

Chaîne montagneuse de la Madonie

Sicile
L'abri sous roche du Vallone Inferno est un nouveau site archéologique situé dans la chaîne montagneuse de la Madonie, en Sicile. Les fouilles archéologiques et les recherches ont révélé une longue séquence préhistorique et historique allant du Néolithique jusqu'à la période médiévale, représentant actuellement le travail le plus complet pour cette aire géographique. Dans cet article, nous présentons les données préliminaires provenant d'une étude multidisciplinaire et basée sur les restes de poteries et d'industries lithiques, ainsi que sur des restes humains, fauniques et végétaux. Les études stratigraphiques ont identifié quatre complexes, parmi lesquels le complexe 3 a fourni la presque totalité des restes archéologiques. Les datations par ${ }^{14} \mathrm{C}$ AMS, obtenues pour quatre échantillons, situent les activités humaines entre 2601 cal BC et 644 cal AD. Ces datations sont cohérentes avec l'attribution culturelle des céramiques et des industries lithiques. Les restes de macrofaune et végétaux montrent une utilisation continue de l'abri pour des activités pastorales. Les données environnementales, obtenues à partir des restes de microvertébrés et archéobotaniques, montrent une aridification et une ouverture du paysage depuis la base vers le sommet de la séquence, comme conséquence de l'impact humain.

(c) 2012 Académie des sciences. Publié par Elsevier Masson SAS. Tous droits réservés.

\section{Introduction}

The Vallone Inferno is located in the Madonie range, one of the main mountain ranges in Sicily, lying in the northern part of the island. The peaks here reach almost $2000 \mathrm{~m}$ a.s.l., and a rich surface and underground water system has arisen, creating an interesting karst region (Fig. 1).

The area of interest is situated at an average altitude of $600 \mathrm{~m}$ a.s.l. and is characterized by flat lands, with a slight slope towards the west and an increasing gradient next to the River Imera; on the opposite side from the site, the eastern part is characterized by a steep slope (with an abrupt rise from 700 to $1400 \mathrm{~m}$ a.s.l.). Carbonate mountains are here surrounded by clays and sandstones, with grazed or cultivated grassland.

From a topographic point of view, Vallone Inferno is a key point where it is possible to identify a strategic gate that links the alluvial valley of the River Imera to the top of the mountain.

Madonie territory has been exploited by human groups since prehistoric times. Palaeoanthropological and archaeological literature has shown that the Madonie area has certainly been inhabited since the end of the Neolithic and the Copper Age (Bovio Marconi, 1938, 1979; Giuffrida Ruggeri, 1901-1902). An even earlier Upper Palaeolithic peopling of the area has been attested by sporadic older notices (Baldini et al., 1976; Minà Palumbo, 1869).

The human presence in the Madonie system from the end of the Neolithic to the Early Bronze Age has been attested in Vecchiuzzo cave (800 m a.s.l.) (Bovio Marconi, 1979). The first anthropization of the cave dates back to the Late Neolithic and is evidenced by potsherds from the Diana "facies". The abandonment of the cave seems to coincide with the Early Bronze Age, as attested by sporadic Castelluccio potsherds.

Copper and Bronze Age cultures have been attested in the Chiusilla, Fico and Abisso del Vento caves, in the valley of Isnello (Giuffrida Ruggeri, 1901-1902, 1905; Mannino, 1989). In each case, the researchers note that the cultural evidence is linked to burial contexts.
Furthermore, historical sites have been studied in the areas around the Madonie region, sites such as the archaic-classical Monte d'Oro (Di Stefano, 1978) and Monte Riparato settlements (Pancucci, 1993) and the Hellenistic necropolis of Polizzi Generosa (Tullio, 1997).

Recent research, carried out in the context of a major survey project on the territory of the Greek colony of Himera (Belvedere et al., 1988, 2002), has proved that the first systematic exploitation of the area by human groups goes back at least to the Middle Neolithic, as attested by the open-air site of Rocca del Drago, situated in the lower part of the Imera river valley, close to the coast (Forgia, 2002), and by the Bommartino cave, in the higher part of the same valley, on the opposite side from the Vallone Inferno rock-shelter (Belvedere and Forgia, 2010). For the Palaeolithic period, just a few surface findings (lithics) prove the human presence in the early part, as in the case of the Battaglietta polje ( $1600 \mathrm{~m}$ a.s.l.), where quartz arenite implements are typologically comparable with other Upper Palaeolithic tools from coastal sites (for example from Riparo del Castello in Termini Imerese or San Teodoro cave at Acquedolci), or the Nipitalva valley (1450 $\mathrm{m}$ a.s.l.) just above Vallone Inferno, where local flint has been exploited, as attested by cores and flakes scattered along the route there (Forgia, 2009).

The palynological studies of Bertolani Marchetti et al. (1984) showed, for the first time in Sicily, the evolution of the local environment from the Late Pleistocene, when a beech forest dominated the mountainous landscape, through the Preboreal, with an absolute chronology of $9200 \pm 90$ BP obtained by fossil woods, to the Atlantic, when a deciduous oak wood (with dominant Quercus petraea) came to predominance. More specifically, Noti et al. (2009) describe the vegetation around the coastal lake Biviere di Gela (Southern Sicily) during the past 7000 years, like a Mediterranean forest adapted to relatively arid conditions. Their data suggest that forest and shrub land cover reached a maximum between 7000 and 5000 cal B.P., probably in response to moister (or less arid) conditions and low human impact. From that moment, the aridification and human activities contribute to the 


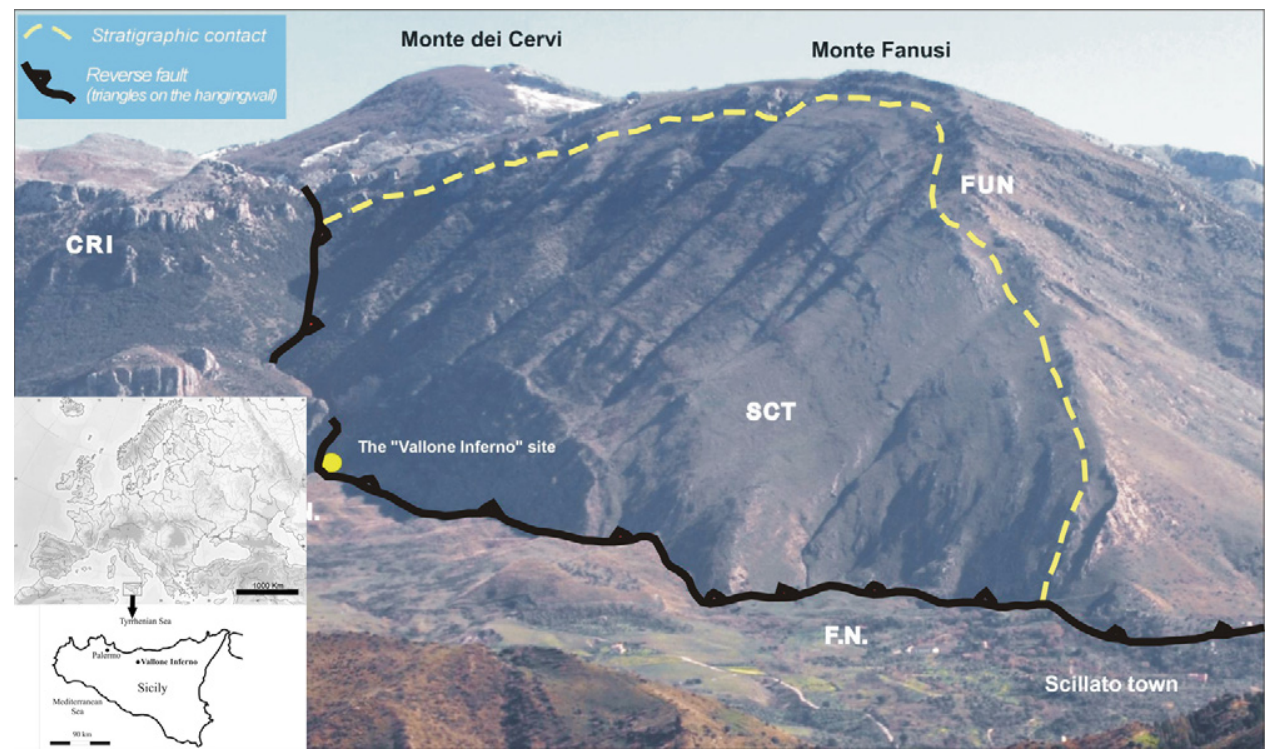

Fig. 1. Panoramic view and stratigraphic sketch of the Vallone Inferno site in the Madonie area (Palermo, Sicily). Imerese Basin Domain: SCT: calcilutites with chert nodules alternating with radiolarian-bearing marls (Upper Carnian-Raethian); FUN: dolomitic breccias (Lower Liassic); CRI: siliceous shales, radiolarian interbedded with resedimented calcareous megabreccias (Upper Liassic-Upper Cretaceous); Numidian Flysch Basin Domain: F.N.: sandy pelites with interbedded arenaceous layers (Upper Oligocene-Lower Miocene).

Fig. 1. Vue panoramique et schéma stratigraphique du site de Vallone Inferno dans la Madonie (Palerme, Sicile). Domaine du Bassin Imerese: SCT: calcilutites avec nodules de chert alternant avec des marnes à radiolaires (Carnien-Rhétien supérieur); FUN : brèches dolomitiques (Lias inférieur); CRI : argiles schisteuses siliceuses, intercalations de radiolaires et de méga-brèches calcaires resédimentées (Lias supérieur-Crétacé supérieur); Domaine du Bassin de flysch numidien : F.N. : pélites sableuses avec niveaux sableux intercalés (Oligocène supérieur-Miocène inférieur).

gradual reduction of tree cover. The dates of Biviere di Gela show that the conversion of forests into the very open cultural landscape occurs at ca. 2600 cal B.P. primarily because the human land-use related to the Greek colonization.

Against this background, we here present the first excavation of a stratified archaeological deposit testifying to a long-term human occupation that begins in the prehistoric period and has continuity until contemporary times, the preliminary results of an interdisciplinary research project, and the related implications for our knowledge of palaeoeconomic and palaeoenvironmental dynamics.

\section{Site description}

The site named Vallone Inferno is a rock-shelter located at ca. $770 \mathrm{~m}$ a.s.l. in the municipality of Scillato, Sicily, Italy; its coordinates are $37^{\circ} \mathrm{C} 52^{\prime} 17.74^{\prime \prime} \mathrm{N}$ and $13^{\circ} 55^{\prime} 58.97^{\prime \prime} \mathrm{E}$.

Vallone Inferno (also known as Fosso Inferno) is a deep gorge which cuts through the northern slope of Monte dei Cervi-Monte Fanusi, a complex fault escarpment at the northwestern margin of the Madonie massif, which shows evidence of neotectonic activity. In this sector, the massif is modelled into the Triassic to Oligocene sedimentary rocks of the Imerese Basin, in which carbonate, siliceous and terrigenous lithologies (limestone, sometimes cherty, dolomite, marl, clay, radiolarite etc.) alternate with one another (Fig. 1). The origin of the gorge is chiefly fluviokarstic, though structural and tectonic factors also played a role in its development.
The rock-shelter is located at the foot of the left wall of Vallone Inferno, almost at the exit of the escarpment, facing the gentle slope that is found downstream, where Cenozoic terrains of Numidian Flysch and slope sediment outcrop.

The formation of the rock-shelter is mainly related to karstic dissolution, which was controlled at the same time by the structural layout of the local bedrock (cherty limestone and dolomitic limestone belonging to the Scillato geological formation).

The archaeological interest of Vallone Inferno was recognized in the context of the major survey project on the Madonie mountain range (Forgia, 2008, 2009). One of the sample areas chosen for the project was an intermediate area lying between local inland uplands (more than $1600 \mathrm{~m}$ a.s.l.) and lowlands (around $500 \mathrm{~m}$ a.s.l.) near the Imera river valley. The site immediately showed its importance, because an abrupt section of the 5-m archaeological deposit was clearly exposed by the Inferno stream.

The archaeological sequence is at present $5 \mathrm{~m}$ deep in total, and the archaeological investigation covers an area of $30 \mathrm{~m}^{2}$.

The rock-shelter is more than $10 \mathrm{~m}$ long and $6 \mathrm{~m}$ deep and is oriented to north (Fig. 2A). The water stream is close to the shelter, the gorge is narrow, and the visibility from the rock-shelter is reduced to a small portion of the Imera river valley and of the coastal area.

\section{Material and methods}

The international team, already established during the survey project, planned a first research campaign in 

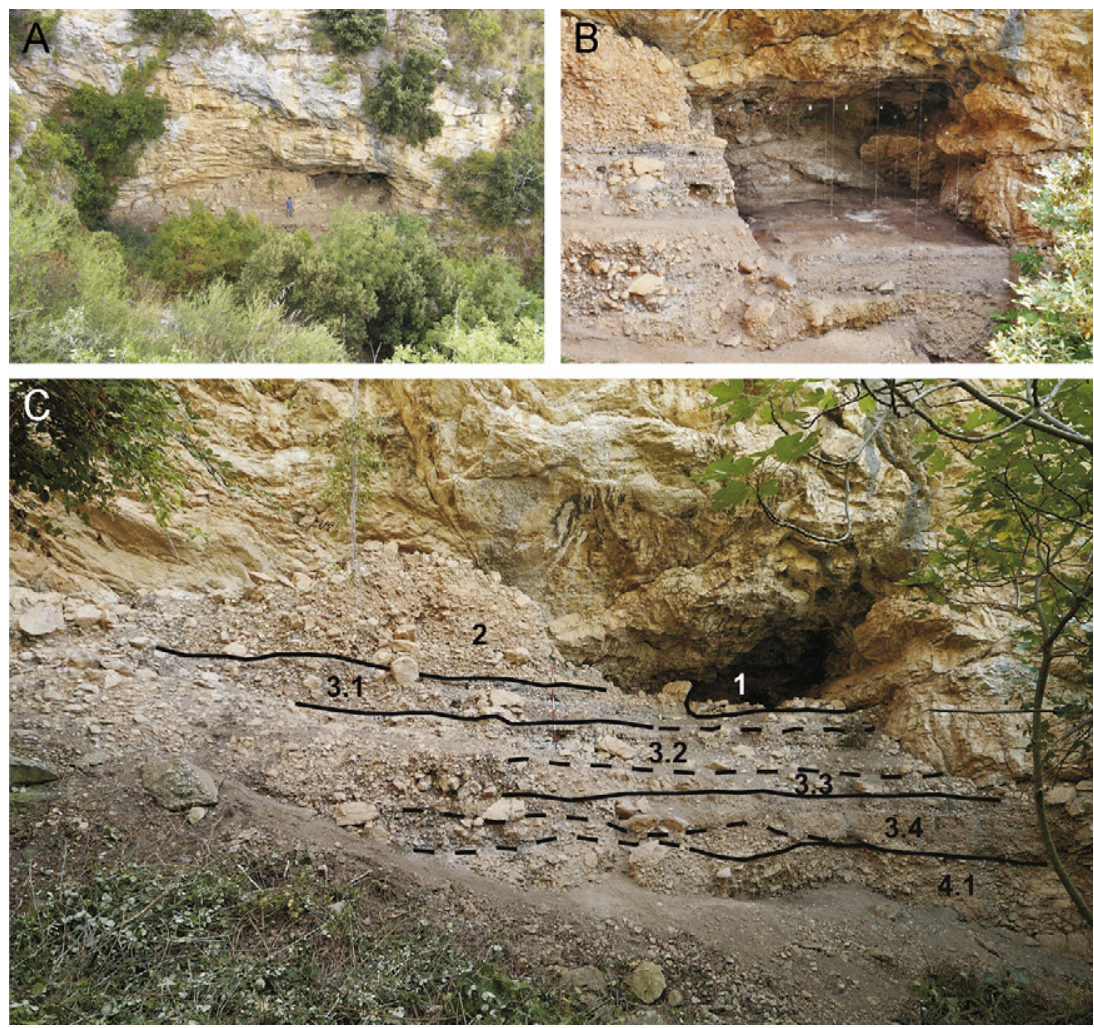

Fig. 2. A. General view of the Vallone Inferno rock-shelter in 2008, before the excavation. B. The excavated area at the top of unit 3.4.A, at the end of the 2011 season. C. Frontal view of the sedimentary succession and initial stratigraphic sketch (2008).

Fig. 2. A. Vue générale de l'abri sous roche de Vallone Inferno en 2008, avant de la fouille. B. La surface de fouillée au sommet de l'unité 3.4.A, à la fin de l'intervention de 2011. C. Vue frontale de la succession sédimentaire et schéma stratigraphique initial.

order to investigate this exceptional archaeological and palaeoenvironmental sequence.

In the first excavation campaign (2008) the work focused on a first exploration of the sequence. The section of deposit was cleaned, and a preliminary excavation was started on the section running east-west (with respect to the theoretical north of the excavation). In places a limited area of the lower section was cleaned. Archaeological units were established according to sedimentary criteria. We used numbers to designate the stratigraphic units and subunits, and letters to refer to minor divisions (Fig. 2C). These were specified according to minor sedimentary differences as well as archaeological features (such as burnt sediment, structures, etc.).

From 2009 to 2011 the upper part of the section was investigated over an area of about $30 \mathrm{~m}^{2}$ (from layer 1.1 to layer 3.3.0), and the middle and lower parts of the section were partially explored (from layer 3.4.A to layer 4.2) (Fig. 2B).

Each find (lithic, pottery and faunal remains, as well as samples of a different nature) was 3D recorded. Micromammal remains were collected by water screening, archaeobotanical remains of no use for radiocarbon dating were recovered using water flotation. Samples of sediment were taken from each sub-layer and from fireplaces for archaeobotanical analysis.

\section{Stratigraphy and chronological data}

The Vallone Inferno rock-shelter was almost filled by a thick deposit, within which four main stratigraphic complexes were identified. From the top to the base these are as follows (Fig. 3A and B):

- complex 1: stone walls and structures dating to the 20th century;

- complex 2: calcareous breccias, ca. $2.5 \mathrm{~m}$ thick, which outcrop on the site's magnetic east side and do not contain any archaeological evidence. They are made up of massive (top) to poorly-stratified (bottom) clastsupported heterometric angular fragments of limestone with occasional chert elements, with clayey-silt organic fine material filling the space among coarse components. The complex dips $\mathrm{W} / 8^{\circ}$, and a discontinuous layer of laminated silty sand is found at its lower boundary, an erosive (paraconformity) surface;

- complex 3: the archaeological succession, which consists of an alternation of fine-textured archaeological layers and coarser beds. The archaeological succession (complex 3) was split into four subcomplexes, which are as follows, from the top to the base: 


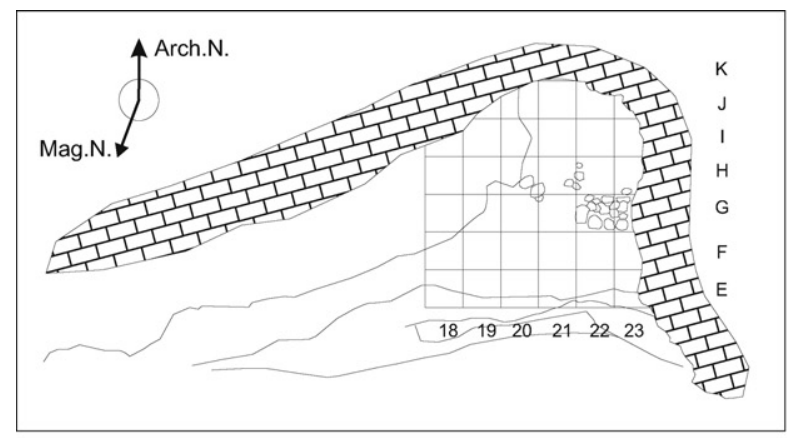

A
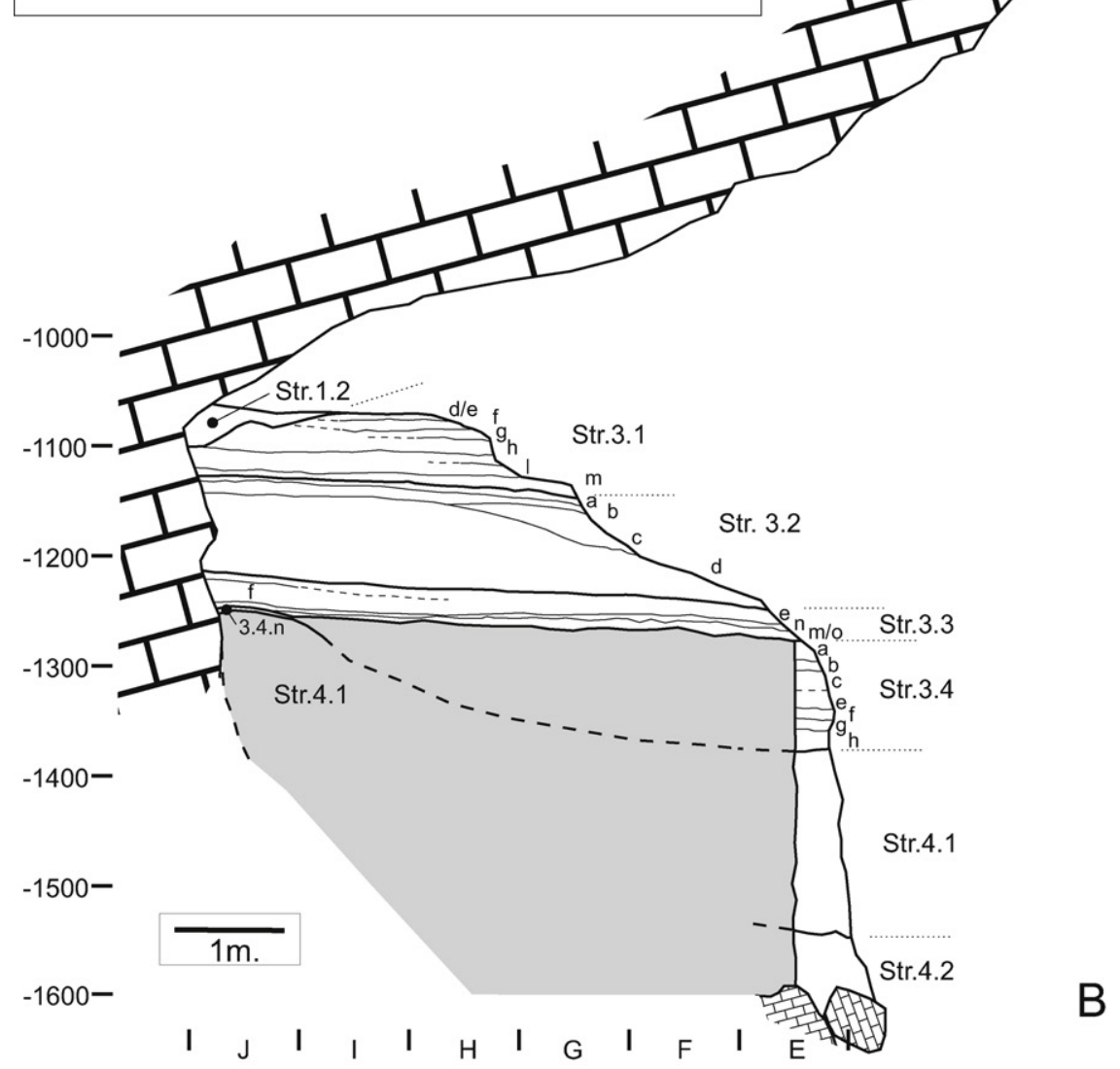

B

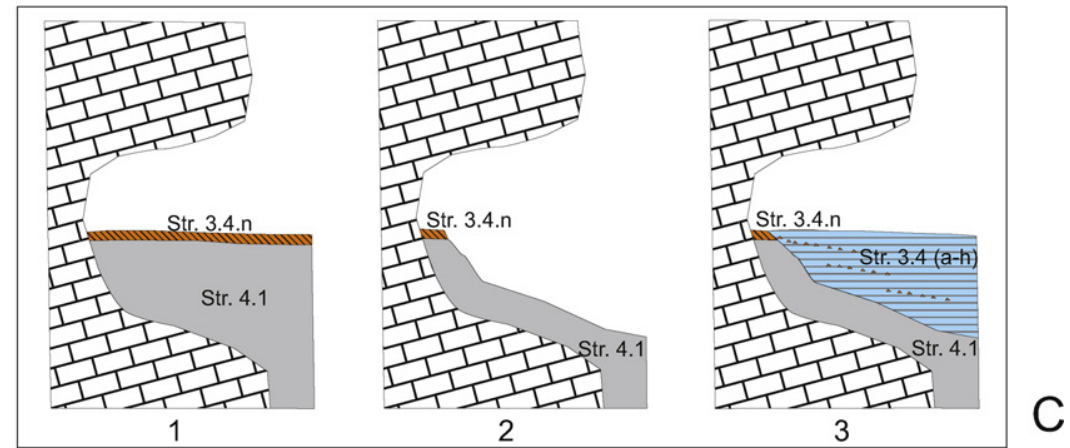

Fig. 3. A. General plan of the Vallone Inferno archaeological area, before the excavation. B. Synthetic stratigraphic sequence; the cut corresponds to the contact between lines 20 and 21 (although for units 3.1 to 3.3 it corresponds to the 19-20 contact). C. Deposition-erosion-deposition cycle that would explain the incorporation of Neolithic-Tricromica pottery (from str. 3.4.N) into the more recent levels (3.4.A to 3.H).

Fig. 3. A. Plan général de la surface archéologique de Vallone Inferno avant la fouille. B. Séquence stratigraphique synthétique; la coupe correspond au contact entre les lignes 20 et 21 (si bien pour les unités 3.1 à 3.3 elle correspond au contact 19-20). C. Dynamiques de déposition et érosion du sous-complexe 3,4 qui expliquent la incorporation de poterie du type Tricromica (provenant de la couche 3.4.N) dans des niveaux plus récents (3.4.A à 3H). 
Table 1

Calendric ages obtained through CalPal'07 calibration software (Weninger and Jöris, 2004) and CalPal 2007 Hulu combined curve (Weninger and Jöris, 2008).

Tableau 1

Datations radiocarbone de la séquence du Vallone Inferno.

\begin{tabular}{|c|c|c|c|c|c|c|c|c|}
\hline Lab. ID & Layer & Sample & Method & $\begin{array}{l}\text { Conventional } \\
\text { Radiocarbon } \\
\text { Age (BP) }\end{array}$ & SD & $\begin{array}{l}\text { Calibrated Radiocarbon } \\
\text { Age (AD/BC) (1 sigma, } \\
68 \%)\end{array}$ & $\begin{array}{l}\text { Calibrated Radiocarbon } \\
\text { Age (AD/BC) ( } 2 \text { sigma, } \\
95 \%)\end{array}$ & $\begin{array}{l}\text { Calibrated Radiocarbon } \\
\text { Age (BP) ( } 2 \text { sigma, 95\%) }\end{array}$ \\
\hline DSH2816 & 3.1.1 & Vegetal remain & AMS & 1260 & 34 & $742 \pm 49$ calAD & $644-840$ calAD & $1320-1120$ calBP \\
\hline DSH2814 & 3.2.c & Charcoal & AMS & 1332 & 26 & $678 \pm 28$ calAD & $622-734$ calAD & 1340-1220 calBP \\
\hline DSH2815 & 3.4.b & Seed & AMS & 3244 & 42 & $1527 \pm 58$ calBC & $1643-1411$ calBC & $3600-3360$ calBP \\
\hline DSH1976 & $3.4 . \mathrm{g}$ & Human bone & AMS & 3948 & 35 & $2455 \pm 73$ calBC & 2601-2309 calBC & 4550-4270 calBP \\
\hline Beta-314642 & 4.2 & Charcoal & AMS & 9450 & 50 & $8750 \pm 84$ calBC & 8918-8582 calBC & 10860-10540 calBP \\
\hline
\end{tabular}

- subcomplex 3.1 includes ashy and thermoaltered beds alternating with coarse, stony beds with ByzantineLate Roman archaeological materials,

- subcomplex 3.2 is a fining-upward sequence including archaeological materials of a Late Roman date,

- subcomplex 3.3 includes organic and thermoaltered beds alternating with coarser beds and contains Late Roman remains,

- subcomplex 3.4 is made up of an alternation of coarse and fine layers - the latter often enriched with organic matter and featuring prehistoric assemblages (Early Bronze and Middle Neolithic in age) - which comprise four sedimentary cycles including a complex deposition-erosion-deposition dynamics. The current state of research points to the existence of a first Neolithic occupation of the cave (Str. 3.4.N), a strong erosion that affected most of that level and also the top of the underlying complex 4, and the subsequent sedimentation of the Bronze Age levels. The erosion of the remaining sediments of Str. 3.4.N would explain the incorporation of Neolithic pottery (Tricromica) into the more recent levels (Fig. 3C);

- complex 4: poorly-stratified, partially open work, calcareous breccias, moderately cemented by calcium carbonate. Coarse components are angular to subangular and heterometric, while fine material is brown silty loam. The complex is ca. $2 \mathrm{~m}$ thick, shows local imbrications of coarse components, and contains an intercalation of brown silty sand featuring two thin ash layers at the bottom (subcomplex 4.2). Although microvertebrates and pollen grains have been preliminarily identified in this unit, it has not been excavated and no information other than its dating is offered here.

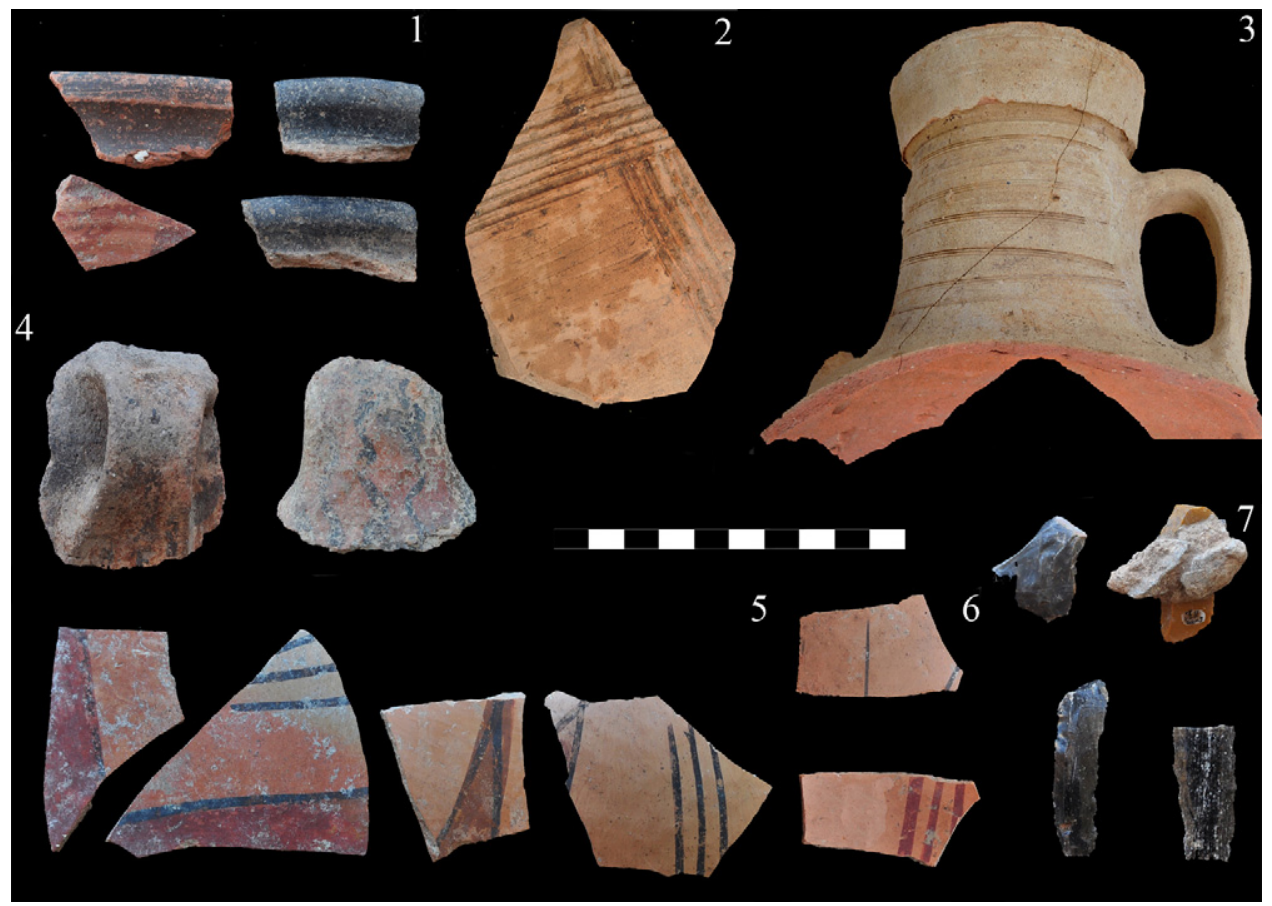

Fig. 4. Some ceramic and lithic remains from the Vallone Inferno subcomplexes. 1. Domestic pottery and cooking ware sherds. 2. Late Roman tile. 3. Amphora fragment: Keay LXI A. 4. Early Bronze Age handles. 5-6. Middle Neolithic-Tricromica potsherds. 6. Flint and obsidian implements.

Fig. 4. Quelques restes de céramique et d'industries lithiques des sous-complexes du Vallone Inferno. 1. Poterie domestique et tessons d'ustensiles de cuisson. 2. Tuile romaine récente. 3. Fragment d'amphore: Keay LXI A.4. Anses de l'Âge du Bronze ancien. 5-6. Néolithique moyen-Tessons de poterie du type Tricromica. 6. Outils en silex et obsidienne. 
Five samples have been selected from the sequence for radiocarbon dating by AMS: four come from complex 3 and have been analysed at Circe Innova Lab; the last is from subcomplex 4.2 and has been analysed by Beta analytic Inc (Table 1).

\section{Archaeological data}

\subsection{Pottery}

For this study 520 ceramic fragments were analysed. Pottery typology of the Late Roman and possibly the Byzantine period comes from subcomplexes 3.1 and 3.2; this consists of storage and transport ware such as fragments of jugs, dolia and amphorae, several items of cooking ware and building materials such as tile fragments. Particularly noteworthy in subcomplex 3.2 is an amphora, Keay LXI A (Fig. 4), dated to the 7th century $\mathrm{AD}$, a chronology that is coherent with the radiocarbon date obtained for this subcomplex (Table 1).

The ceramic typology of subcomplex 3.3 is mainly characterized by a significant number of amphora fragments (129), an almost complete balm unguentarium and several cooking and common ware fragments (Fig. 4).

Pottery wares characteristic of the local Early Bronze and Middle Neolithic were recorded in subcomplex 3.4. The Early Bronze Age is represented by local Castelluccio "facies". Altogether four painted fragments were recovered, among which a remarkable fragment of the handle of a large vessel stands out. Middle Neolithic pottery fragments are more numerous; 10 engraved grey ware potsherds and 34 of Tricromica were documented. Among the latter is a remarkable fragment of a characteristic closed vessel with a long neck, and open shapes, mainly painted plates showing decoration on both surfaces (Fig. 4).

\subsection{Lithic artefacts}

The lithics from Vallone Inferno rock-shelter are currently represented by 107 remains. The most significant lithic record, which is from the prehistoric subcomplex 3.4 , amounts to 79 pieces of a variety of raw materials: flint is represented by 49 pieces (61.25\%); obsidian is represented by 18 pieces (22.5\%); quartz, quartzite and sandstone are each represented by one piece; and finally 10 limestone pieces are present (Fig. 4). Autoptic analysis recognizes as local the provenience of raw material for the flint assemblage (Jurassic-Cretaceous Crisanti Formation), and obsidian likely comes from Lipari.

The flint assemblage consists of 12 (24\%) simple flakes, six (12\%) flake fragments, 11 (22\%) angular fragments and three (6\%) retouched flakes. In addition, there is a significant amount of flint specimens (34\%) that remain dubious due to the presence in the deposit of natural flint fragments. The obsidian assemblage consists of seven (38\%) simple flakes, three (16\%) flake fragments and eight (44\%) fragments. No knapping activities in situ have been recognized. Preliminary functional analyses of the assemblage showed the general good conditions of the implement surfaces.
Table 2

Faunal list from the Vallone Inferno subcomplexes.

Tableau 2

Liste faunique des sous-complexes du Vallone Inferno.

\begin{tabular}{|c|c|c|c|c|}
\hline & 3.1 & 3.2 & 3.3 & 3.4 \\
\hline \multicolumn{5}{|l|}{ Macromammals } \\
\hline Bos taurus & $\mathrm{x}$ & & $\mathrm{X}$ & $\mathrm{x}$ \\
\hline Sus sp. & $\mathrm{X}$ & $\mathrm{X}$ & $\mathrm{X}$ & $\mathrm{X}$ \\
\hline Ovis aries/Capra hircus & $\mathrm{x}$ & $\mathrm{x}$ & $\mathrm{X}$ & $\mathrm{X}$ \\
\hline Cervus elaphus & $\mathrm{X}$ & $\mathrm{x}$ & $\mathrm{X}$ & $\mathrm{X}$ \\
\hline Dama dama & $\mathrm{X}$ & $\mathrm{x}$ & $\mathrm{X}$ & \\
\hline Lagomorpha & $\mathrm{X}$ & & & $\mathrm{X}$ \\
\hline Canis familiaris & & $\mathrm{x}$ & $\mathrm{x}$ & $\mathrm{X}$ \\
\hline Canis lupus & $\mathrm{x}$ & & & \\
\hline Carnivora & $\mathrm{X}$ & & & $\mathrm{x}$ \\
\hline \multicolumn{5}{|l|}{ Micromammals } \\
\hline Erinaceus europaeus & & & & $\mathrm{X}$ \\
\hline Crocidura cf. C. sicula & $\mathrm{x}$ & & & $\mathrm{x}$ \\
\hline Suncus etruscus & & & & $\mathrm{x}$ \\
\hline Myotis gr.myotis-blythii & & & & $\mathrm{x}$ \\
\hline Arvicola cf. A. terrestris & & & & $\mathrm{x}$ \\
\hline Microtus (Terricola) savii & $\mathrm{X}$ & & & $\mathrm{x}$ \\
\hline Apodemus sylvaticus & $\mathrm{X}$ & & & $\mathrm{X}$ \\
\hline Rattus norvegicus & $\mathrm{X}$ & & & \\
\hline Eliomys quercinus & $\mathrm{x}$ & & & $\mathrm{x}$ \\
\hline Glis glis & $\mathrm{x}$ & $\mathrm{X}$ & & $\mathrm{x}$ \\
\hline Muscardinus avellanarius & & & $\mathrm{X}$ & \\
\hline \multicolumn{5}{|l|}{ Avifauna } \\
\hline Aves indet. & & $\mathrm{X}$ & $\mathrm{X}$ & $\mathrm{x}$ \\
\hline \multicolumn{5}{|l|}{ Herpetofauna } \\
\hline Discoglossus cf. D. pictus & $\mathrm{X}$ & & & \\
\hline cf. Bufo bufo & & $\mathrm{x}$ & & \\
\hline Tarentola sp. & $\mathrm{X}$ & & & \\
\hline Lacerta gr. L. viridis & $\mathrm{x}$ & & & $\mathrm{x}$ \\
\hline cf. Podarcis & $\mathrm{x}$ & & & $\mathrm{X}$ \\
\hline Testudo sp. & $\mathrm{X}$ & & & \\
\hline Elaphe cf. E. quatuorlineata & $\mathrm{x}$ & & & $\mathrm{x}$ \\
\hline Vipera gr. V. aspis & & & & $\mathrm{X}$ \\
\hline Ophidia indet. & $\mathrm{X}$ & & & $\mathrm{X}$ \\
\hline
\end{tabular}

\subsection{Faunal remains}

The large-mammal assemblage is composed of 1446 remains. The species identified can be classified into two groups according to their origin: domestic and wild species (Table 2). Ovicaprines (Ovis aries and Capra hircus) and pigs (Sus scrofa domestica) are the two main categories in the sequence as a whole; these species are most numerous and the only ones represented throughout the archaeological succession (the sum of these three species makes up more than $50 \%$ of the total of the specific identified remains) (Table 2).

Differences in specific representation over the course of the sequence allow a change in the stockbreeding management to be observed between historic and prehistoric subcomplexes. Whereas the pig is the basis of historic exploitations, ovicaprines are the most important taxon in prehistoric times. Further, the large presence of immature individuals observed, in pigs $(3.1,3.2,3.3)$ and in ovicaprines (3.4), might be an indicator of the development of breeding activity in the rock-shelter during a more or less lengthy period.

This stockbreeding economy was complemented with hunting activity. This has been documented throughout the 
Table 3

Archaeobotanical remains from the Vallone Inferno sequence. Tableau 3

Restes archéobotaniques de la séquence du Vallone Inferno.

\begin{tabular}{|c|c|c|c|c|}
\hline & 3.1 & 3.2 & 3.3 & 3.4 \\
\hline \multicolumn{5}{|l|}{ Crops } \\
\hline Hordeum sp. & $\mathrm{X}$ & & $\mathrm{X}$ & \\
\hline Hordeum vulgare nudum & $\mathrm{X}$ & & & \\
\hline Hordeum vulgare vulgare & $\mathrm{X}$ & & & \\
\hline Lens culinaris & & $\mathrm{X}$ & & \\
\hline Pisum sativum & $\mathrm{X}$ & & $\mathrm{X}$ & \\
\hline Triticum aestivum/durum & $\mathrm{X}$ & & $\mathrm{X}$ & $\mathrm{X}$ \\
\hline Triticum dicoccum & & & $\mathrm{X}$ & \\
\hline cf. Vicia faba & & & $\mathrm{X}$ & \\
\hline \multicolumn{5}{|l|}{ Fruits } \\
\hline cf. Olea sp. & & & $\mathrm{X}$ & \\
\hline cf. Pinus sp. & & & $\mathrm{X}$ & \\
\hline cf. Quercus sp. & $\mathrm{X}$ & $\mathrm{X}$ & $\mathrm{X}$ & $\mathrm{X}$ \\
\hline Rubus fruticosus/idaeus & $\mathrm{X}$ & & & \\
\hline Rubus sp. & & & & $\mathrm{X}$ \\
\hline cf. Vitis sp. & $\mathrm{X}$ & & & \\
\hline \multicolumn{5}{|l|}{ Weeds } \\
\hline Bromus sp. & $\mathrm{X}$ & & $\mathrm{X}$ & \\
\hline Carex sp. & $\mathrm{X}$ & & & \\
\hline Fumaria officinalis & & & & $\mathrm{X}$ \\
\hline Galium aparine & & & $\mathrm{X}$ & \\
\hline Leguminosae (Fabaceae) & $\mathrm{X}$ & $\mathrm{X}$ & $\mathrm{X}$ & \\
\hline Malva sp. & $\mathrm{X}$ & & & \\
\hline \multicolumn{5}{|l|}{ Outbreaks } \\
\hline cf. Rosaceae & $\mathrm{X}$ & $\mathrm{X}$ & & $\mathrm{X}$ \\
\hline \multicolumn{5}{|l|}{ Charcoal } \\
\hline Acer & $\mathrm{X}$ & $\mathrm{X}$ & $\mathrm{X}$ & $\mathrm{X}$ \\
\hline Cistaceae & & $\mathrm{X}$ & & \\
\hline Erica sp. arborea & & & & $\mathrm{X}$ \\
\hline Ficus carica & $\mathrm{X}$ & $\mathrm{X}$ & & \\
\hline Fraxinus & $\mathrm{X}$ & $\mathrm{X}$ & $\mathrm{X}$ & $\mathrm{X}$ \\
\hline Hedera helix & & & & $\mathrm{X}$ \\
\hline Leguminosae & $\mathrm{X}$ & $\mathrm{X}$ & & $\mathrm{X}$ \\
\hline Lonicera & $\mathrm{X}$ & & & \\
\hline Maloideae & $\mathrm{X}$ & $\mathrm{X}$ & & $\mathrm{X}$ \\
\hline Olea europaea & $\mathrm{X}$ & $\mathrm{X}$ & $\mathrm{X}$ & $\mathrm{X}$ \\
\hline Pistacia cf. terebinthus & & $\mathrm{X}$ & & $\mathrm{X}$ \\
\hline Pistacia lentiscus & $\mathrm{X}$ & & & \\
\hline Quercus sp. & $\mathrm{X}$ & $\mathrm{X}$ & $\mathrm{X}$ & $\mathrm{X}$ \\
\hline Quercus deciduous & $\mathrm{X}$ & $\mathrm{X}$ & $\mathrm{X}$ & \\
\hline Quercus evergreen & $\mathrm{X}$ & $\mathrm{X}$ & $\mathrm{X}$ & $\mathrm{X}$ \\
\hline Rhamnus alaternus/Phillyrea & $\mathrm{X}$ & & $\mathrm{X}$ & $\mathrm{X}$ \\
\hline Sambucus & $\mathrm{X}$ & $\mathrm{X}$ & $\mathrm{X}$ & \\
\hline Thymelaceae & $\mathrm{X}$ & & & \\
\hline Vitis vinifera & $\mathrm{X}$ & & & \\
\hline Angiosperma undeterminate & $\mathrm{X}$ & $\mathrm{X}$ & $\mathrm{X}$ & $\mathrm{X}$ \\
\hline Bark & & $\mathrm{X}$ & & \\
\hline cf. Fraxinus & & & & $\mathrm{X}$ \\
\hline cf. Olea europea & & & & $\mathrm{X}$ \\
\hline cf. Prunus & & & $\mathrm{X}$ & \\
\hline cf. Sambucus & $\mathrm{X}$ & $\mathrm{X}$ & & \\
\hline \multicolumn{5}{|l|}{ Pollen } \\
\hline Pinus sp. & $\mathrm{X}$ & $\mathrm{X}$ & & \\
\hline cf. Juniperus & $\mathrm{X}$ & $\mathrm{x}$ & & \\
\hline Quercus deciduous & $\mathrm{X}$ & $\mathrm{X}$ & & $\mathrm{X}$ \\
\hline Quercus evergreen & $\mathrm{X}$ & $\mathrm{X}$ & & $\mathrm{X}$ \\
\hline Olea sp. & & $\mathrm{X}$ & & \\
\hline Corylus sp. & $\mathrm{X}$ & $\mathrm{X}$ & & $\mathrm{X}$ \\
\hline Salix sp. & $\mathrm{X}$ & $\mathrm{X}$ & & $\mathrm{X}$ \\
\hline Fraxinus sp. & $\mathrm{X}$ & & & \\
\hline Ulmus sp. & $\mathrm{X}$ & $\mathrm{X}$ & & \\
\hline Castanea type & $\mathrm{X}$ & & & \\
\hline Erica spp. & $\mathrm{X}$ & $\mathrm{X}$ & & $\mathrm{X}$ \\
\hline Helianthemum sp. & $\mathrm{X}$ & $\mathrm{X}$ & & \\
\hline Ephedra distachya type & $\mathrm{X}$ & & & \\
\hline
\end{tabular}

Table 3 (Continued)

\begin{tabular}{|c|c|c|c|c|}
\hline & 3.1 & 3.2 & 3.3 & 3.4 \\
\hline Rosaceae & $\mathrm{X}$ & & & \\
\hline Hedera & $\mathrm{X}$ & & & \\
\hline Buxus sp. & & $\mathrm{X}$ & & \\
\hline Cistaceae & & $\mathrm{X}$ & & \\
\hline Poaceae & $\mathrm{X}$ & $\mathrm{X}$ & & $\mathrm{X}$ \\
\hline Cerealia type & $\mathrm{X}$ & $\mathrm{X}$ & & $\mathrm{X}$ \\
\hline Asteraceae tubuliflorae & $\mathrm{X}$ & $\mathrm{X}$ & & $\mathrm{X}$ \\
\hline Asteraceae liguliflorae & $\mathrm{X}$ & $\mathrm{X}$ & & $\mathrm{X}$ \\
\hline Artemisia & $\mathrm{X}$ & & & \\
\hline Plantago sp. & $\mathrm{X}$ & $\mathrm{X}$ & & $\mathrm{X}$ \\
\hline Apiaceae & $\mathrm{X}$ & $\mathrm{X}$ & & $\mathrm{X}$ \\
\hline Chenopodiaceae & $\mathrm{X}$ & $\mathrm{X}$ & & $\mathrm{X}$ \\
\hline Leguminosae & $\mathrm{X}$ & $\mathrm{X}$ & & $\mathrm{X}$ \\
\hline Valerianaceae & & $\mathrm{X}$ & & \\
\hline Scrophulariaceae & $\mathrm{X}$ & & & $\mathrm{X}$ \\
\hline Liliaceae & & & & $\mathrm{X}$ \\
\hline Armeria sp. & & & & $\mathrm{X}$ \\
\hline Caryophyllaceae & $\mathrm{X}$ & $\mathrm{X}$ & & $\mathrm{X}$ \\
\hline Asphodelus sp. & $\mathrm{X}$ & $\mathrm{X}$ & & \\
\hline Solanaceae & & $\mathrm{X}$ & & \\
\hline Lamiaceae & $\mathrm{X}$ & $\mathrm{X}$ & & \\
\hline Scabiosa sp. & $\mathrm{X}$ & $\mathrm{X}$ & & \\
\hline Urticaceae & $\mathrm{X}$ & $\mathrm{X}$ & & \\
\hline Campanulaceae & $\mathrm{X}$ & $\mathrm{X}$ & & \\
\hline Malvaceae & $\mathrm{X}$ & & & \\
\hline Ranunculaceae & $\mathrm{X}$ & $\mathrm{X}$ & & $\mathrm{X}$ \\
\hline Cyperaceae & $\mathrm{X}$ & $\mathrm{X}$ & & \\
\hline Typha/Sparganium & $\mathrm{X}$ & $\mathrm{X}$ & & $\mathrm{X}$ \\
\hline
\end{tabular}

sequence, with the presence of a variety of wild mammal species (such as red deer, fallow deer and rabbits).

\subsection{Human remains}

Our analysis identified 33 human specimens, all from subcomplex 3.4 (and therefore Middle Neolithic or Early Bronze in age), with a preponderance of dental remains (76\%). The non-dental remains are fragmentary and are associated with the hand and foot skeleton. Considered in their totality, the dental remains can be ascribed to a minimum of two adults and one infant. Dental damage is present but limited. In one sample caries is present.

\subsection{Small-vertebrate remains}

The small-vertebrate assemblage studied consists of remains of anurans, squamate reptiles, insectivores, chiropters and rodents and includes a total of 300 fragments, which correspond to a minimum number of 170 smallvertebrates, representing at least 19 taxa (Table 2). There are not sufficient data to undertake a palaeoenvironmental interpretation for subcomplexes 3.1, 3.2 and 3.3. However, the small-vertebrate association from subcomplex 3.4 suggests that the environment was dominated by taxa linked to humid meadows, as indicated by the abundance of Microtus (Terricola) savii. On the other hand, the presence of Apodemus sylvaticus, Glis glis and Vipera gr. V. aspis in this subcomplex indicates open forest cover. 


\subsection{Archaeobotany}

\subsubsection{Carpological remains}

In the course of the carpological study, 114 remains recovered from the various subcomplexes of Vallone Inferno were analysed (Table 3). Crops, fruits and weeds are represented by 21 taxa (Table 3). Most of them are charred seeds, although 14 uncharred remains of Vitis sp. (grape vine) and fragments of rachis and shoots (possibly from the Rosaceae family) have also been documented.

The seeds come mostly from cultivated plants and fruits. Within the group of crops, two wheat species Triticum aestivum/durum (bread/durum wheat) and Triticum dicoccum (emmer) have been documented; the first is the most significant in terms of percentage representation, whereas the remaining species of crops appear in smaller quantities. Cultivated pulses are represented by Lens culinaris (lentil), Pisum sativum (pea) and cf. Vicia faba (broad bean), representing less than $4 \%$ of the total remains. Fruits are represented by 6 taxa, the most abundant of which is Quercus sp. (acorn).

Weeds are documented to a lesser extent, representing only $14.88 \%$ of the total; 6 taxa were identified, the most numerous being Fabaceae and Bromus sp. (bromes). The remaining taxa are present in very low percentages.

Other interesting remains for this study are shoots (10.53\%), possibly from the family Rosaceae, which may have been used for livestock foddering.

\subsubsection{Charcoal}

A total of 19 taxa have been identified, showing great variability among the different phases. According to the relative values per phase, the most significant taxon is Quercus; Quercus sp. evergreen is more important in the three upper phases (3.1, 3.2 and 3.3) and Quercus sp. deciduous in the lower phase (3.4). Other significant taxa according to their relative values are Olea europaea and Fraxinus. Taxa such as Acer and Rhamnus alaternus/Phillyrea are less represented, showing values around $3 \%$ and $10 \%$. In terms of the ubiquity of the taxa, the results do not show any significant changes; phase 3.3 is the one that shows the lowest number of taxa (8), whereas phase 3.1 shows the largest spectrum (15) (Table 3).

\subsubsection{Pollen analysis}

Only eight samples have provided results in terms of pollen residue, representing subcomplexes 3.1, 3.2 and 3.4. According to cluster analysis, the samples are grouped into two main sets, zone A and B. Zone A, which includes samples belonging to subcomplexes 3.2 and 3.4 , is characterized by a high percentage representation of arboreal taxa (around 20 to 50\%). Zone B, made up of isolated samples from subcomplex 3.1, reported minimum values of arboreal pollen (around 7 to $20 \%$ ). The pollen results reveal a landscape formed by a mixed oak forest. In the most disadvantaged or higher-altitude areas, Pinus and cf.Juniperus were able to proliferate. Areas beside rivers or water streams would develop a well-formed riverside forest. We have also identified the presence of elements from the regional vegetation context such as Betula, which probably came from the surrounding mountains (Table 3).

\section{Discussion}

The stratigraphic succession at Vallone Inferno is relevant for understanding the palaeoenvironmental evolution and human occupation of the margin of the Madonie massif from the beginning of the Holocene to the Late Roman period.

Middle Neolithic occupation is represented at Vallone Inferno by Tricromica ceramics and by the associated engraved pottery (undisturbed subcomplex 3.4.N). Vallone Inferno represents one of the few examples of a stratified context of exclusively Tricromica ware, which has been considered a phenomenon of importation in late Stentinello culture (Bernabò Brea, 1958) as opposed to the Stentinello ware that has often been recovered in Sicily. Nowadays, the presence of sites or chrono-cultural horizons showing an exclusively Tricromica production different from the late stage of the Stentinello culture is starting to emerge clearly also in Sicily. The stratigraphy at Vallone Inferno has shown that an erosive event almost totally destroyed the Middle Neolithic layers and that Bronze Age settlements, as attested by the pottery record discussed below, mixed the cultural elements of the two epochs - with a gap between the second half of the fifth millennium BC. and the beginning of the third. With respect to lithic industry, we underline the presence of obsidian, which seems to be associated mainly with the Middle Neolithic occupation of the rock-shelter, a period in which the circulation of obsidian in the area starts to assume a wide-ranging importance. Moreover, the substitution of Stentinello culture by Tricromica groups at Lipari, and the presence of the latter in Sicily, could testify to a monopoly in the obsidian trade by Tricromica groups, as suggested by Bernabò Brea and Cavalier (1980).

In subcomplex 3.4 a ceramic record of the Castelluccio "facies" of the Early Bronze Age is also represented. Together with the record from Bommartino cave on the opposite side of the River Imera, this provides us with first indications of the diffusion of this painted style along the valley. The Castelluccio "facies" has often been associated with a mature stage of an economic system based on agriculture and pastoralism and with a cultural environment mainly known from the Southeast of Sicily and apparently absent from the northern coast, where the coeval unpainted "facies" of Rodì-Tindari and Moarda seem to be predominant. The presence along the Imera river valley and its immediate surroundings (Vecchiuzzo cave) of painted pottery from the Late Copper and Early Bronze Ages underlines how this area stands out from the innermost areas of the Madonie range, where only unpainted Copper/Bronze Age horizons (Abisso del Vento, Fico, Chiusilla caves and nearby open-air sites) have been recorded. Along with the Nebrodi, the Madonie Mountains constitute the only true mountain range, with peaks around $2000 \mathrm{~m}$ a.s.l., towards which people and cultures (especially related to pastoralism) converge, leaving traces of themselves, but not deleting the local traditions. The mountains divide communities who live there permanently, but at the same 
time are a pole of attraction for communities coming from different districts. This provides a possible interpretation for the arrival, from the south, of groups of humans that seasonally exploited this part of the mountains and for the sporadic presence (out of stratigraphic context) at Vallone Inferno of a Bell beaker - as a fragment - linked to the western tradition.

Moreover, the presence of human remains in subcomplex 3.4 suggests a possible funerary use of Vallone Inferno, limited to the prehistoric period. The direct AMS- ${ }^{14} \mathrm{C}$ dating of a human specimen, the first from the Madonie range, to the second half of the third millennium BC shows that this could be linked to an Early Bronze Age inhumation within the rock-shelter. This enriches the limited human record of the area as regards Copper and Bronze Age cave burials (Fico, Chiusilla and Abisso del Vento: Giuffrida Ruggeri, 1901-1902; 1905; Mannino, 1989).

The historical sequence of the Vallone Inferno pottery record (subcomplex 3.1-3.3), which is actually poor from a typological and a functional point of view, seems to reflect the temporary use of the rock-shelter by small human groups probably involved in seasonal pastoral activities. Some of the potsherds directly recall similar specimens from the surrounding area, where the presence of a Late Roman territorial system involving the whole Madonie range (Forgia, 2009) suggests that the human groups of Vallone Inferno might have originated from nearby settlements located a few $100 \mathrm{~m}$ to the north, at a slightly lower altitude in a flat area. According to Traina (1994) and Vera (1995), the preference for the natural environment and marginal land in the Late Roman period is well exemplified by the Vallone Inferno area, where the highlands support and complement a mid-altitude settlement pattern, in an integrated territorial system.

In this respect, the function of the site during the Late Roman and Byzantine period is clearly shown by subcomplexes 3.1, 3.2 and 3.3, all of them interesting for their dung-burning practices, while within layer 3.2.C three hearths are documented. One of the most interesting burnt dung surfaces is that of layer 3.3.N, which is clearly associated with a sheepfold (3.3.K) and with four fireplaces. With regard to pastoral practices, four caves have been investigated in the Madonie territory (Brochier et al., 1992), of which three (two of them very close to Vallone Inferno) presented burnt manure layers in sub-recent deposits.

Carpological, charcoal and archaeozoological results agree in defining the function of the site as a shelter for herding activity throughout the sequence.

Firstly, domestic animals are the main faunal resources in all the subcomplexes studied. In the prehistoric ones, ovicaprines are the basis of livestock management, as has been observed in other prehistoric Italian sites with a sheepfold context (Rowley-Conwy, 1997; Tagliacozzo, 2005). In the historic subcomplex, a change in the stockbreeding structure is observed, since domestic suids are the main taxon.

On the other hand, the charcoal record shows the use of the shelter for different purposes. In all the phases a preference for Olea europaea, Fraxinus and Quercus has been documented, which might be associated with the activities that took place in the shelter related mainly to the feeding of livestock. These three taxa, especially Fraxinus and Olea europaea, are very much appreciated as fodder for goat and sheep herds (Allué, 2005; Badal, 1999; Delhon et al., 2008). Likewise, blackberry (Rubus fruticosus/idaeus and Rubus sp.), as shown by carpological data (3.1/3.4), could either be identified as animal fodder or interpreted as food that was grazed from hedges (Akeret and Jacomet, 1997; Akeret and Rentzel, 2001).

Moreover, the decrease in the dominance of deciduous oak in archaeological layers 3.1-3.3 (Late Roman/Byzantine) could be related to the intensification of human activities, which, according to other studies, are well documented from the Bronze Age on. Sadori et al. (2008) suggest that forest clearance by burning and the intense use of wood for a variety of purposes (metallurgy, construction) might have caused a decline in the arboreal cover leading to the decrease in deciduous oaks. Deciduous Quercus has its main peak at ca. 8000 years BP; its subsequent decrease starts slowly but is very noticeable at ca. 3500 years BP (Sadori et al., 2004, 2008).

Finally, in reference to the seasonality of the occupation site, the presence of shoots along the whole archaeological sequence at Vallone Inferno, probably harvested in the early spring, might be related with immature ovicaprine individuals, which are usually born in the last days of winter or the first days of spring in the Mediterranean region (Balasse and Tresset, 2007; Helmer et al., 2005). On the other hand, the abundance of deciduous ovicaprine teeth in the prehistoric levels shows an intense occupation at that time, since these elements fall preferentially within the sheepfold when the animal is eating (Helmer et al., 2005). The palaeoenvironmental data, enriching and agreeing with the results of previous studies (Allué et al., 2009; Carrión et al., 2003; Sadori et al., 2004, 2008), focus upon the aridification and opening of the landscape (Sadori and Giardini, 2007) towards the top of the sequence, as a consequence of the anthropic impact.

The percentages of arboreal pollen (AP) at Vallone Inferno are low and decrease more markedly towards the end of the sequence; at the same time, evergreen elements are more abundant in the upper units.

Accordingly, at the top of unit 3.2 the presence of Olea and a significant increase in Quercus ilex-coccifera type have been identified. This may be associated with a time of warmer temperatures and a drier environment. All these data agree in ascribing subcomplex 3.4 a higher level of humidity and forest cover. In fact, as previously pointed out by Bonfiglio et al. (2000) for the climate at the beginning of the Holocene in Sicily, the data obtained with our results suggest that this period had a climate similar to today, but with a higher degree of humidity and more extensive forested areas than nowadays, as also suggested by the abundance of Glis glis and the presence of Muscardinus avellanarius and Arvicola cf. A. terrestris in layer 3.4.

\section{Conclusions}

With the absolute ${ }^{14} \mathrm{C}$ AMS dating range from the beginning of the Holocene to the Late Roman period and the archaeological and palaeoenvironmental results, the sequence is of great potential in the context of prehistoric and historical studies. With respect to northwestern Sicily 
in particular, the site of Vallone Inferno could serve as a reference sequence, providing a good set of information from various levels of investigations.

In the course of our multidisciplinary studies the following conclusions have been reached.

The pottery, the faunal record, and to a lesser extent the lithic tools testify to the repeated use of the shelter. Furthermore, our results provide information about the different strategies likely to have been adopted in the exploitation of territories, in a long diachronic view. The function of the site is well documented by the palaeoeconomic evidence, which indicates a clear and persistent use of the shelter for pastoral purposes and also as a sheepfold over the course of time. Vallone Inferno thus represents a key site in the interpretation of pastoral systems, with respect in particular to the origin and the first development of a practice which to this day remains one of the main economic supplies for the area.

Moreover, as revealed by different data, the sequence shows environmental changes over time. At a preliminary stage of the investigation, it is possible to note that the environmental changes seem to be closely associated with the human exploitation of the area. In this regard, however, it does not seem that the main activity documented at the site (related to farming and grazing) can in itself be responsible for such changes. Therefore, the palaeoenvironmental changes could be related more to human pressure resulting from the establishment of more intensive farming systems and the more aggressive exploitation of the forest (wood, charcoal, etc.), especially from the Greek and Roman colonization to the medieval and modern ages.

\section{Acknowledgements}

Financial support to the project came from University of Palermo, Dipartimento di Beni Culturali (Prin 2007, CoRI 2008/2010). V.F. worked in the framework of a MIUR Postdoctoral position 2009-2011 and 2011-2013. The work was also supported by MIUR (ex 60\% f.) funds to L.S. We are grateful to Dr.M.A. Papa for the total-station survey of the rock-shelter (field operations and graphical post-processing) and A. Ceraulo (field operations). We are also grateful for the constant support to Prof. A. Burgio of the University of Palermo, to Dr.S.Vassallo and Dr.R.M.Cucco of the Soprintendenza BB.CC.AA. of Palermo, and Dr. F. Spatafora (Parco archeologico di Himera). The field-work has been supported by Ente Parco delle Madonie, Azienda Foreste Demaniali and Corpo Forestale dello Stato. Thanks to the Municipality of Scillato, in particular to A. Battaglia and to the staff of the Municipality, and special thanks to Salvatore Rizzo.

Besides, this project has been developed in the framework of the Catalan AGAUR projects 2006EXCAVA0023, 2009SGR-000188 and SGR2009-324, and the Spanish MICINN project CGL2009-07896/BTE. Juan Manuel López-García is beneficiary of a postdoctoral fellowship (2011BP-A00272) from the Generalitat de Catalunya, a grant co-funded by the European Union through the Marie Curie Actions for the 7th Framework Program for R+D, with the financial sponsorship of the Spanish Ministry of Science and Innovation and Juan Ignacio Morales is beneficiary of a predoctoral grant FI-DGR 2012 from AGAUR (Generalitat de Catalunya).

\section{References}

Akeret, Ö., Jacomet, S., 1997. Analysis of plant macrofossils in goat/sheep faeces from the Neolithic lake shore of Horgen Scheller: an indication of prehistoric transhumance? Veget. Hist. Archaeobot. 6, 235-239.

Akeret, Ö., Rentzel, P., 2001. Micromorphology and plant macrofossil analysis of cattle dung from the Neolithic lake shore settlement of Arbon Bleiche 3. Geoarchaeology: An International Journal 16 (6), 687-700.

Allué, E., 2005. Aspectos ambientales y económicos durante el Neolítico antiguo a partir de la secuencia antracològica de la Cova de la Guineu (Font Rubí, Barcelona). In: Arias, P., Ontañón, C., García-Moncón, G.(Eds.), III Congreso del Neolítico en la Península Ibérica, 53-61. Santander, Universidad de Cantabria.

Allué, E., Vernet, J.-L., Cebria, A., 2009. Holocene vegetational landscapes of the NE iberia. Charcoal analysis from Cova de la Guineu Barcelona, Spain. The Holocene 19 (5), 765-773.

Badal, E., 1999. El potencial pecuario de la vegetación mediterránea: las cuevas Redil. Saguntum-Plav, Extra 2, 69-76.

Balasse, M., Tresset, A., 2007. Environmental constraints on the reproductive activity of domestic sheep and cattle: what latitude for the herder? Anthropozoologica 42, 71-87.

Baldini, G., Cassataro, U., Longo, E., Recami, A., 1976. Recenti scoperte suI paleolitico siciliano. Natura 67, 125-127.

Belvedere, O., Forgia, V., 2010. Prehistoric settlement and population in the Madonie Mountains. New data from the archaeological survey. In: Archéologie de la montagne européenne. Actes de la table ronde internationale de Gap, 29 septembre-1er octobre 2008. Errance, Centre Camille Jullian. Bibliothèque d'archéologie méditerranéenne et africaine 4, pp. 145-51.

Belvedere, O., Alliata, V., Cusimano, G., Marescalchi, P., Vassallo S., 1988. Himera III.1. Prospezione archeologica nel territorio. Roma: L'Erma di Bretschneider, XII + 229 p.

Belvedere, O., Bertini, A., Boschian, G., Burgio, A., Contino, A., Cucco, R.M., Lauro, D., 2002. Himera III.2. Prospezione archeologica nel territorio. Roma: L'Erma di Bretschneider, XXXVIII + 455 p.

Bernabò Brea, L., Cavalier, M., 1980. Meligunìs Lipàra IV, L'Acropoli di Lipari nella preistoria, Palermo, 875 p.

Bernabò Brea, L., 1958. La Sicilia prima dei Greci. Il Saggiatore, Milano, 262 p.

Bertolani Marchetti, D., Accorsi, C.A., Arobba, D., Bandini Mazzanti, M., Bertolani, E., Biondi, G., Braggio, G., Ciuffi, C., De Cunzo, T., Della Ragione, S., Forlani, L., Guido, A.M., Lolli, F., Montanari, C., Paoli, P., Raimondo, F.M., Rossitto, M., Trevisan Grandi, G., 1984. Recherches géobotaniques sùr les Monts Madonie (Sicile du nord). Webbia 38, 329-348.

Bonfiglio, L., Mangano, M., Marra, A.C., Masini, F., Pavia, M., Petruso, D., 2000. Pleistocene Calabrian and Sicilian bioprovinces. Geobios 35, 29-39.

Bovio Marconi, J., 1938. La cultura di Isnello e il cuprolitico occidentale. Bullettino di Paletnologia Italiana, n. s. 2, 44-56.

Bovio Marconi, J., 1979. La grotta del Vecchiuzzo presso Petralia Sottana (Serie Archeologica, 1). G. Bretschneider, Roma, 108 p.

Brochier, J.E., Villa, P., Giacomarra, M., Tagliacozzo, A., 1992. Shepherds and sediments: Geo-ethnoarchaeology of pastoral sites. Journal of Anthropological Archaeology 11 (1), 47-102.

Carrión, J.S., Sánchez-Gómez, P., Mota, J.F., Yll, E.I., Chaín, C., 2003. Holocene vegetation dynamics, fire and grazing in the Sierra de Gádor, southern Spain. The Holocene 13 (6), 839-849.

Delhon, C., Martin, L., Argant, J., Thiébault, S., 2008. Shepherds and plants in the Alps: multi-proxy archaeobotanical analysis of Neolithic dung from "La Grande Rivoire" (Isère, France). Journal of Archaeological Science 35 (11), 2937-2952.

Di Stefano, C.A., 1978. Monte d'Oro di Collesano, Paropos e “qal'at as-sirat”. Sicilia Archeologica XI 38, 30-41.

Forgia, V., 2002. Nuovi rinvenimenti di età preistorica a Cozzo Rocca del Drago, in Belvere O. et al., Himera III.2, Roma, pp.427-435.

Forgia, V., 2008. Mountain environment and landscape in prehistoric Sicily: the Madonie region (Palermo, Italy). In: Grimald, S. and Perrin, T. (Eds.), UISPP Proceedings of the XV World Congress (Lisbon, 4-9 September 2006), Vol.26, Session C31, Mountain Environments in Prehistoric Europe, Settlement and mobility strategies from Palaeolithic to the Early Bronze Age, BAR S1885, pp.165-169.

Forgia, V., 2009. Strategie d'insediamento nella Sicilia pre-protostorica. Un esempio dal sistema montuoso delle Madonie (Pa), in AA.VV., Per la conoscenza dei Beni Culturali. II - Ricerche del Dottorato in 
Metodologie conoscitive per la conservazione e la valorizzazione dei Beni Culturali 2004-2009, Seconda Università degli Studi di Napoli, Dipartimento di Studio delle Componenti Culturali del Territorio, Dottorato di Ricerca in Metodologie conoscitive per la conservazione e la valorizzazione dei Beni Culturali, pp.9-24.

Giuffrida Ruggeri, V., 1901-1902. Materiale paletnologico di una caverna naturale di Isnello presso Cefalù in Sicilia. Atti della Società Romana di Antropologia VIII, 337-368.

Giuffrida Ruggeri, V., 1905. Terzo contributo all'antropologia fisica dei Siculi eneolitici. Atti della Società Romana di Antropologia XI, 56-103.

Helmer, D., Gourichon, L., Sidi Maamar, H., Vigne, J.D., 2005. L'élevage des caprins néolithiques dans le Sud-Est de la France: saisonnalité des abattages, relations entre grottes-bergeries et sites de plein air. Anthropozoologica 40 (1), 167-189.

Mannino, G., 1989. L'abisso del Vento. Sicilia Archeologica 69-70, 49-52.

Minà Palumbo, F., 1869. Paletnologia sicula delle armi in pietra raccolte in Sicilia, Palermo.

Noti, R., van Leeuwen, J.F.N., Colombaroli, D., Vescovi, E., Pasta, S., La Mantia, T., Tinner, W., 2009. Mid- and Late-Holocene vegetation and fire history at Biviere di Gela, a coastal lake in southern Sicily, Italy. Vegetation History and Archaeobotany 18, 371-387.

Pancucci, D. 1993. Monte Riparato in "Di terra in terra, nuove scoperte archeologiche nella provincia di Palemo, Museo Archeologico Regionale di Palermo", Palermo pp.204-14.

Rowley-Conwy, P., 1997. The Animal Bones from Arene Candide. Final Report. In: Maggi, R. (Ed.), Arene Candide: Functional and Environmental Assessment of the Holocene Sequence. Ministero per i Beni Culturali e Ambientali, Rome.
Sadori, L., Giardini, M., 2007. Charcoal analysis, a method to study vegetation and climate of the Holocene: the case of Lago di Pergusa (Sicily, Italy). Geobios 40, 173-180.

Sadori, L., Giraudi, C., Petitti, P., Ramrath, A., 2004. Human impact at Lago di Mezzano (central Italy) during the Bronze Age: a multidisciplinary approach. Quaternary International 113 (1), 5-17.

Sadori, L., Zanchetta, G., Giardini, M., 2008. Last Glacial to Holocene palaeoenvironmental evolution at Lago di Pergusa (Sicily, southern Italy) as inferred by pollen, microcharcoal, and stable isotopes. Quaternary International 181 (1), 4-14.

Tagliacozzo, A., 2005. Animal Exploitation in the Early Neolithic in centralsouthern Italy. Homenaje a Jesús Altuna, Munibe I, 429-439.

Traina, A., 1994. Paesaggi tardoantichi: alcuni problemi. In: Francovich, R., Noyè, G. (Eds.), La storia dell'Alto Medioevo italiano (VI-X secolo) alla luce dell'archeologia. Atti del Convegno internazionale, Firenze.

Tullio, A., 1997. La necropoli ellenistica di Polizzi Generosa (C.da San Pietro) a cinque anni dalla scoperta (1992-1996). Archeologia e territorio, Palermo, pp. 267-274.

Vera, D., 1995. Dalla "villa perfecta" alla villa di Palladio: sulle trasformazioni del sistema agrario in Italia fra Principato e Dominato, Athenaeum n.s. LXXXIII, 189-211, pp. 331-356.

Weninger, B., Jöris, O., 2004. Glacial Radiocarbon Calibration. The CalPal Program. Radiocarbon and Archaeology. In: Ramsey D.B. and Owen C. (Ed.), Fourth International Symposium. 2002. Oxford.

Weninger, B., Jöris, O., 2008. A ${ }^{14} \mathrm{C}$ age calibration curve for the last $60 \mathrm{ka}$ : the Greenland-Hulu U/Th timescale and its impact on understanding the Middle to Upper Paleolithic transition in western Eurasia. J. Human Evol. 55 (5), 772-781. 